\title{
WHY DO ALBINOS AND OTHER HYPOPIGMENTED MUTANTS LACK NORMAL BINOCULAR VISION, AND WHAT ELSE IS ABNORMAL IN THEIR CENTRAL VISUAL PATHWAYS?
}

\author{
R. W. GUILLERY \\ Oxford
}

\section{EARLY OBSERVATIONS OF THE PATHWAY ABNORMALITY}

It is now 30 years since Lund $^{1}$ first described the abnormally small uncrossed retinotectal pathways of albino rats. The subsequent discovery of a similar abnormality in the retinogeniculate pathways of Siamese cats ${ }^{2}$ was broadened in $1971{\text { by } \mathrm{Creel}^{3} \text { into }}^{2}$ a generalisation about all mammals homozygous for a mutation at the albino locus. He based his generalisation on the fact that Siamese cats are homozygous for an allele at this locus. This proposed generalisation was rapidly confirmed for several different mammalian forms, including rabbits, ${ }^{4}$ mice, ${ }^{5}$ mink, ${ }^{6}$ ferrets, ${ }^{7}$ guinea pigs, ${ }^{8}$ monkeys ${ }^{9,10}$ and tigers. ${ }^{11}$ Strictly speaking it was only one tiger, one of the 'white' tigers that can now be seen in several zoos, and it was not an albino tiger, but a chinchilla tiger. That is, this animal, like the Siamese cat, was homozygous for an allele at the albino locus, and its lateral geniculate nucleus showed an abnormal lamination that was comparable to an abnormality of geniculate lamination previously described for Siamese cats ${ }^{2}$ and there readily ascribed to the abnormally small uncrossed pathway.

\section{CHARACTERISATION OF THE GENETIC BASIS OF THE PATHWAY ABNORMALITY IN HUMAN AND OTHER ALBINO MAMMALS}

This early research led in two different directions. One, perhaps of primary interest here, concerned the occurrence of the abnormality in albino humans. Evoked potential studies early demonstrated the reduced uncrossed pathway to the visual cortex, ${ }^{12,13}$

Correspondence to: R. W. Guillery, Department of Human Anatomy, South Parks Road, Oxford OX1 3QX, UK. and since the tiger had shown that post-mortem brain sections could be used to demonstrate the characteristic abnormal fusions of geniculate laminae, it was not long before the abnormal structure of the lateral geniculate nucleus in human albinos had also been demonstrated. ${ }^{14}$

At first sight it seemed that the occurrence of the abnormality of the optic chiasm in mutants homozygous for a well-characterised gene might reveal a developmental chain of events that would take us from the gene through the enzyme (tyrosinase for the albino locus) to the mechanisms controlling axonal pathways at the optic chiasm. This hope has been sadly, but as I shall show, not surprisingly, disappointed. Stent ${ }^{15}$ wrote a thoughtful analysis of the Siamese abnormality as a model of developmental studies. He pointed out that even though we know the gene, and know the enzyme, we have no idea at all about how the abnormal pathway at the optic chiasm is produced. And that remains true today. The passage from gene action to developmental mechanisms is rarely simple. It can be complex and difficult to analyse, and has proved so for the chiasmatic abnormality of albinos.

Some clear evidence about the complexity of the situation was already present in earlier literature about the human condition. Witkop and colleagues ${ }^{16}$ had shown that genetically there was more than one type of albinism, which Witkop had called tyrosinase positive and tyrosinase negative albinism since one form had essentially normal levels of tyrosinase which the other lacked. Both showed essentially the same visual abnormalities, suggesting that the visual abnormalities associated with albinism could not be simply ascribed to the lack of tyrosinase demonstrable in the albino animals that had an abnormal

Eye (1996) 10, 217-221 (C) 1996 Royal College of Ophthalmologists 
chiasmatic structure. The human brains that showed the abnormal geniculate lamination were from tyrosinase positive patients,${ }^{14}$ and evoked potential methods showed the reduced uncrossed pathway not only in tyrosinase negative and tyrosinase positive subjects but also in other hypopigmented mutants that have been defined. ${ }^{12,13}$

A study of hypopigmented mink ${ }^{6}$ showed much the same situation as did the human studies. These mink were readily available, and genetically well defined since mink ranchers put particularly high value on the pelts of the hypopigmented animals. It was found that any hypopigmented animal shows a reduced uncrossed retinofugal pathway provided that the hypopigmentation includes the melanin of the retinal pigment epithelium. The melanin of the rest of the body is not relevant to the production of the abnormality, a conclusion that receives support from the earlier observation that ocular albinism (an $\mathrm{X}$-linked form of albinism that affects the melanin of the eye only) shows the same visual abnormalities and the same evoked potential patterns as the full form of (oculocutaneous) albinism. ${ }^{13}$

This evidence is further reinforced by observations of several genetically distinct hypopigmented mice which also showed the reduced uncrossed pathway. ${ }^{5}$ These observations, which also indicated, as did the mink studies, that the size of the misrouted retinofugal component was related to the severity of the retinal melanin abnormality, took attention away from the albino gene itelf and from the tyrosinase. Instead, it now seemed necessary to focus on the melanin abnormality. Any mutation, no matter what its locus, that produces an abnormal level of synthesis, an abnormal packaging, or an abnormal distribution of melanin in the retinal pigment epithelium seems also to produce the chiasmatic abnormality. The recent description ${ }^{17}$ of the production of normal central pathways in albino mice by the introduction of a functional tyrosinase transgene confirms the relationship between the albino gene and the pathway abnormality, but has so far added nothing to our understanding of the relevant developmental mechanisms.

Although it is possible to propose developmental mechanisms that might link the melanin abnormalities to the pathway abnormality, we have no hard evidence at all about what may actually be happening. In large part this may be because we understand so little about the way in which the optic chiasm develops in normal or in abnormal animals. The early development of the optic chiasm is a complex issue ${ }^{18}$ in itself, and the ways in which this may possibly be related to hypopigmentation of the retinal pigment epithelium remain a mystery and will not be explored further here.

\section{OTHER ABNORMALITIES IN ALBINO AND HYPOPIGMENTED MAMMALS}

In addition to the abnormality of the retinofugal pathway, albinos show an abnormality of the distribution of retinal cells, including the ganglion cells and the photoreceptors..$^{19,20}$ In the human retina this presents as an absence of a well-formed fovea, ${ }^{21,22}$ and is generally seen as a reduction in the number and the packing density of cells in the central parts of the retina. It is reasonable to expect that the developmental mechanisms responsible for the pathway abnormality also influence the development of the retinal receptor cells, but neither developmental mechanism is understood, nor is any hint available how the two may be related to each other.

The abnormalities of the central visual relays that characterise albino mammals, particularly in the geniculo-cortical pathways, have been studied in some detail, and can be seen as a developmental consequence secondary to the chiasmatic abnormality. A first important step in understanding the chiasmatic abnormality is the recognition that in the abnormal individuals there is a shift in the 'line of decussation, ${ }^{23}$ the line that separates the nasal retina, which has a pure crossed pathway in all mammals, from the temporal retina which gives rise to a pure uncrossed pathway in primates (and fruit bats) and gives rise to mixture of crossed and uncrossed components in all other mammals that have been studied from this point of view. This line is shifted towards the temporal periphery in all the abnormal hypopigmented forms, $, 2,10,23-25$ and this produces a reduction in the uncrossed component with a corresponding increase in the crossed component. That is, it appears that some of the ganglion cells that would send their axons ipsilaterally in a normal animal, take a crossed pathway in the abnormal animals. It has been shown that in Siamese cats the junction between these two segments of the retina lies about $20^{\circ}$ temporal to its normal position at the midline vertical meridian ${ }^{2,24}$ (the cat has a binocular visual field that extends out to about $45^{\circ}$ ). In fully albino cats, which have a more severe melanin deficit than the Siamese cats, and correspondingly more abnormal visual pathways, the segment having abnormally crossed retinofugal fibres (the so-called abnormal segment) is larger, and the normal segment correspondingly smaller. ${ }^{26}$

Whereas in the normal pathway the right lateral geniculate nucleus receives fibres from the right temporal retina, which is looking at the binocular part of the left visual field, in the abnormal animals a part of the right lateral geniculate nucleus instead receives from a part of the left temporal retina, which is looking at some of the binocular part of the right visual field. ${ }^{2}$ This abnormal crossed pathway thus 
brings an abnormal part of the visual field (a part of the ipsilateral visual field within $20^{\circ}$ of the midline vertical meridian) to each lateral geniculate nucleus.

Detailed fibre tracing and physiological recording experiments have shown that the abnormal crossed fibres end in an exact copy of the normal laminar distribution and central/peripheral order. ${ }^{2}$ However, since the left temporal retina is a mirror reversal of the right temporal retina, the abnormal pathway brings a visuotopic order to the relevant geniculate laminae that is a mirror reversal of the normal order and that is, of course, also a mirror reversal relative to the normal order in the crossed pathway still coming from the nasal retina.

The geniculate layers that receive a normal crossed input from the nasal retina are essentially normal in the abnormal animals, but the layers that receive from the temporal retina can be divided into two distinct parts. One part (the abnormal segment) receives a mirror reversed visual input from the central parts of the ipsilateral visual field through the contralateral temporal retina, and the other part (the normal segment) receives an apparently normal input from the peripheral parts of the contralateral visual field through the ipsilateral temporal retina.

Several interesting functional and structural consequences follow from this abnormal arrangement of the retinofugal pathway. At a basic level one finds, as indicated above, that the geniculate laminae show an abnormal structure., $, 6,7,9-11$ Where the abnormal crossed input produces segments in two adjacent laminae that are innervated by the same eye, those two segments tend to fuse. Also, where one lamina receives inputs from both eyes, the two segments tend to separate from each other on the basis of their ocular input. So far as has been determined, in spite of this abnormal laminar arrangement, the response properties of geniculate cells are essentially normal, except of course for the fact that many receptive fields are in the ipsilateral visual field. ${ }^{2,10,24}$

In the visual cortex the situation is more complex. ${ }^{24,27}$ It has been found that in some Siamese cats the geniculocortical projection has an essentially normal topography. In these cats it appears that the cortex is unable to process the afferent messages that are bringing two mirror reversed, contradictory projections from the lateral geniculate nucleus. There are but few cells in the cortex of such cats that respond to images falling on the temporal retina, and behaviourally these cats are blind in the whole temporal retina, ${ }^{28,29}$ not just in the segment that is abnormally innervated. There is no evidence for any binocular vision in area 17 of these cats and, in accord with this, it has been shown that Siamese cats lack stereopsis. ${ }^{30}$ However, there is evidence for binocular cells in extrastriate visual cortical areas, ${ }^{31}$ and some evidence for stereopsis in some albino subjects. $^{32}$

In other cats, the geniculocortical topography is modified, so that the pathway that arises from the abnormally innervated segment of the lateral geniculate becomes reversed, and goes to its own segment of area 17 where it forms an essentially continuous topographic sequence with the normal segment of the geniculocortical projection innervated by the nasal retina. ${ }^{24}$ These cats show no behavioural evidence for any loss of vision in the temporal retina, ${ }^{29}$ but do show some interesting cells that receive a dual input from roughly corresponding parts of the two visual hemifields, suggesting that the geniculocortical pathways have a mixed topography, partially normal, partially with the inversion of the abnormal segment.

There are other abnormalities that are of considerable interest for understanding the developmental controls of normal and abnormal central pathways, and for understanding some of the functional deficits associated with albinism. The cortico-cortical and corticothalamic fibres that arise from the abnormally innervated cortex are themselves abnormal, ${ }^{33.34}$ as though the abnormal activity patterns in the geniculocortical pathways had influenced an abnormal development of the corticofugal projections. Other retinofugal pathways, such as the one to the superior colliculus, also appear to be abnormal. ${ }^{35.36}$ Since the mirror reversed representation of the visual field will be carried in each of the retinofugal pathways coming from the ipsilateral temporal retina, it is not surprising that eye-movement controls are abnormal, ${ }^{37-39}$ and that a horizontal nystagmus is an abnormality commonly found in albino and hypopigmented subjects. ${ }^{13,38}$

Classical views about the structure of the optic chiasm in mammals assumed that the brain could only function adequately if it receives an orderly projection from each eye, and if these two projections are brought into register somewhere in the brain for a visual image to form. ${ }^{40-42}$ The abnormalities described here give this view some credence for the cerebral cortex. It appears that where some degree of sequential visuotopic order is not created in the cortex, behavioural evidence of vision is absent. $^{29}$ It is of considerable developmental significance that the thalamocortical pathways of some Siamese cats (and $\operatorname{mink}^{43}$ ) appear to have the capacity to recreate visuotopic order from the disorderly geniculo-cortical input. In contrast to this, lower brain centres appear to lack this capacity, and the abnormal eye movements that tend to characterise albino subjects are one of the relatively common results. Recently, these abnormal eye movements have helped to draw attention to an entirely different abnormality of the optic chiasm. 
This is a complete absence of any crossing, ${ }^{44,45}$ which is described elsewhere in this issue. ${ }^{46}$ Although the developmental mechanisms producing the albino and the achiasmatic abnormality are almost certainly quite different, the central consequences are likely to be very similar and each can help to illuminate our understanding of how the central visual pathways operate to produce a smoothly functioning system of perception and motor control.

\section{REFERENCES}

1. Lund RD. Uncrossed visual pathways of hooded and albino rats. Science 1965;149:1506-7.

2. Guillery RW, Kaas JH. A study of normal and congenitally abnormal retino-geniculate projections in cats. J Comp Neurol 1971;143:73-100.

3. Creel D. Visual system anomaly associated with albinism in the cat. Nature 1971;231:465-6.

4. Sanderson KJ. Retino-geniculate projections in the rabbits of the albino allelomorphic series. J Comp Neurol 1975;159:15-28.

5. LaVail JH, Nixon RA, Sidman RL. Genetic control of retinal ganglion cell projections. J Comp Neurol 1978;182:399-422.

6. Sanderson KE, Guillery RW, Shackelford RM. Congenitally abnormal visual pathways in mink (Mustela vison) with reduced retinal pigment. J Comp Neurol 1974;154:225-48.

7. Guillery RW. An abnormal retino-geniculate projection in the albino ferret (Mustelo furo). Brain Res 1971;33:482-5.

8. Creel DJ, Giolli RA. Retinogeniculostriate projections in guinea pigs: albino and pigmented strains compared. Exp Neurol 1972;37:411-25.

9. Gross KJ, Hickey TL. Abnormal laminar patterns in the lateral geniculate nucleus of an albino monkey. Brain Res 1980;190:231-7.

10. Guillery RW, Hickey TL, Kaas JH, Felleman DJ, DeBruyn EJ, Sparks DL. Abnormal central visual pathways in the brain of an albino green monkey (Cercopithecus aethiops). J Comp Neurol 1984; 226:165-83.

11. Guillery RW, Kaas JH. Genetic abnormality of visual pathways in a 'white' tiger. Science 1973;180:1287-9.

12. Creel DJ, Witkop CJ, King RA. Asymmetric visually evoked potentials in human albinos: evidence for visual system anomalies. Invest Ophthalmol 1974;13:430-40.

13. Apkarian P. Albinism. In: Heckenlively JR, Arden $\mathrm{GB}$, editors. Principles and practice of clinical electrophysiology: St Louis: CV Mosby, 1991:773-82.

14. Guillery RW, Okoro AN, Witkop CJ. Abnormal visual pathways in the brain of a human albino. Brain Res 1973;96:373-7.

15. Stent GS. Paradoxes of progress. San Francisco: WH Freeman, 1978.

16. Witkop CJ Jr., Nance WE, Rawls RF, White JG. Autosomal recessive oculocutaneous albinism in man: evidence for genetic heterogeneity. Am J Hum Genet 1970;22:55-74.

17. Jeffery G, Schütz G, Montoliu L. Correction of abnormal retinal pathways found with albinism by introduction of a functional tyrosinase gene in transgenic mice. Dev Biol 1994;166:460-4.

18. Guillery RW, Mason CA, Taylor JSH. Developmental determinants at the mammalian optic chiasm. J Neurosci 1995;15:4727-37.

19. Stone J, Rowe MH, Campion JE. Retinal abnormalities in the Siamese cat. J Comp Neurol 1978;180:773-82.

20. Jeffery G, Darling K, Whitmore A. Melanin and the regulation of mammalian photoreceptor topography. Eur J Neurosci 1993;6:657-67.

21. Elschnig A. Zur Anatomie des menschlichen Albinoauges. Graefes Arch Ophthalmol 1913;84:401-19.

22. Fulton AB, Albert DM, Craft JL. Human albinism: light and electron microscopy study. Arch Ophthalmol 1978;96:305-10.

23. Stone J, Campion JE, Leicester J. The naso-temporal division of the retina in the Siamese cat. J Comp Neurol 1978;180:783-98.

24. Hubel DH, Wiesel TN. Aberrant visual projections in the Siamese cat. J Physiol (Lond) 1971;218:33-62.

25. Chan SO, Guillery RW. Developmental changes produced in the retinofugal pathways of rats and ferrets by early monocular enucleations: the effects of age and the differences between normal and albino animals. J Neurosci 1993;13:5277-93.

26. Creel DJ, Hendrickson A, Leventhal A. Retinal projections in tyrosinase-negative albino cats. J Neurosci 1982;2:907-11.

27. Kaas JH, Guillery RW. The transfer of abnormal visual field representations from the dorsal lateral geniculate nucleus to the visual cortex in Siamese cats. Brain Res 1973;59:61-95.

28. Elekessy EI, Campion JE, Henry GH. Differences between visual fields of Siamese and common cats. Vision Res 1973;13:2533-43.

29. Guillery RW, Casagrande VA. Studies of the modifiability of the visual pathways in Midwestern Siamese cats. J Comp Neurol 1977;174:15-46.

30. Packwood J, Gordon B. Stereopsis in normal domestic cat, Siamese cat, and cat raised with alternating monocular occlusion. J Neurophysiol 1975;38:1485-99.

31. Zeki S, Fries W. A function of the corpus callosum in the Siamese cat. Proc R Soc Lond B 1980;207:249-58.

32. Apkarian P, Reits D. Global stereoposis in human albinos. Vision Res 1989;29:1359-70.

33. Montero VM, Guillery RW. Abnormalities of the corticogeniculate pathway in Siamese cats. J Comp Neurol 1978;179:1-12.

34. Shatz CJ, LeVay S. Siamese cat: altered connections of the visual cortex. Science 1979;204:328-30.

35. Kalil RE, Jhaveri SR, Richards W. Anomalous retinal pathways in the Siamese cat: an inadequate substrate for normal binocular vision. Science 1971;174:302-5.

36. Weber JT, Kaas JH, Harting JK. Retinocollicular pathways in Siamese cats: an autoradiographic study. Brain Res 1978;148:189-96.

37. Collewijn H, Winterson BJ, Dubois MFH. Optokinetic eye movements in albino rabbits: inversion in anterior visual field. Science 1978;199:1351-3.

38. Collewijn H, Apkarian P, Spekreijse H. The oculomotor behaviour of human albinos. Brain 1985;108:1-28.

39. Mangini NJ, Vanable JW, Williams MA, Pinto LH. The optokinetic nystagmus and ocular pigmentation of hypopigmented mouse mutants. J Comp Neurol 1985;241:191-209.

40. Ramón Cajal S. Histologie du système nerveux de l'homme et des vertébrés. Paris: Maloine, 1911.

41. Polyak S. The vertebrate visual system. Chicago: University of Chicago Press, 1957.

42. Guillery RW. No crossing at the crossing. Nature 1994:367:597-8. 
43. Guillery RW, Oberdorfer MD, Murphy EH. Abnormal retino-geniculate and geniculo-cortical pathways in several genetically distinct color phases of the mink (Mustela vison). J Comp Neurol 1979;185:623-56.

44. Apkarian P, Bour L, Barth PG. A unique achiasmatic anomaly detected in non-albinos with misrouted

retinal-fugal projections. Eur J Neurosci 1994;6:501-7. 45. Williams RW, Hogan D, Garraghty PE. Target recognition and visuotopic maps in the thalamus of achiasmatic mutant dogs. Nature 1994;367:637-9.

46. Apkarian P. Chiasmal crossing defects in disorders of binocular vision. Eye 1996;10:222-32. 